\title{
OCEAN RECIME SHIFT IS DRIVING COLLAPSE OF THE NORTH ATLANTIC RIGHT WHALE POPULATION
}
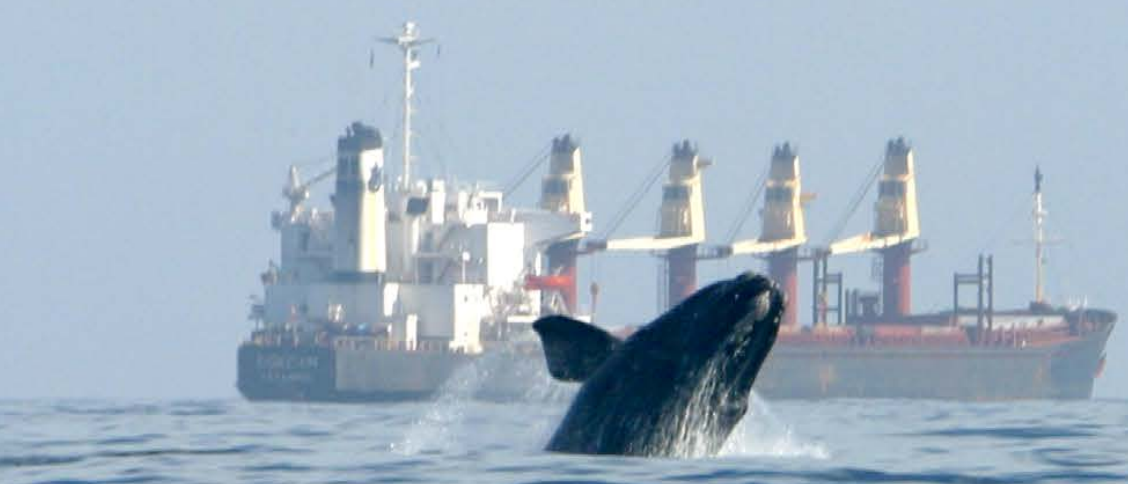

By Erin L. Meyer-Gutbrod, Charles H. Greene,

Kimberley T.A. Davies, and David G. Johns
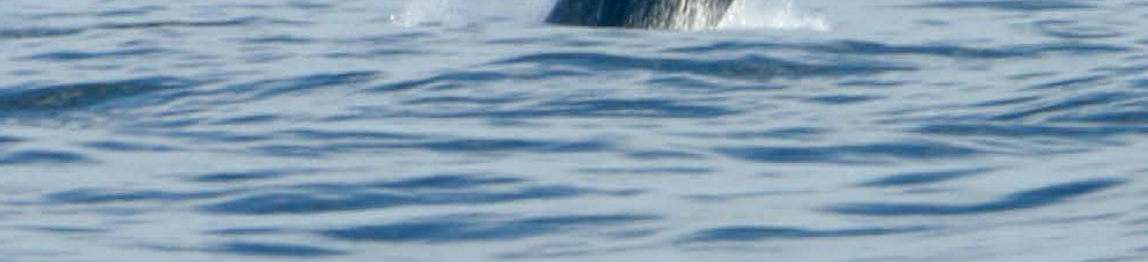

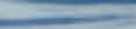
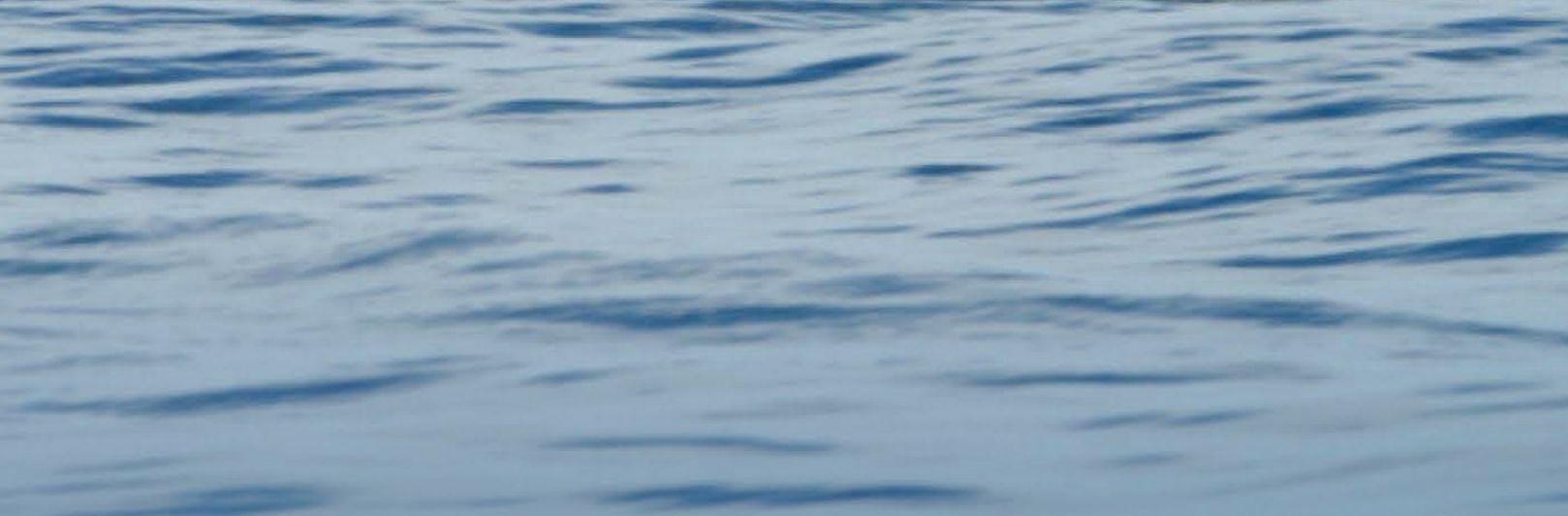

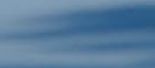

A juvenile right whale breaches against the backdrop of a ship in one of the Seasonal Management Areas implemented by NOAA Fisheries to reduce the likelihood of deaths and serious injuries to these endangered whales that result from collisions with ships. Photo credit: Florida Fish and Wildlife Conservation Commission, NOAA Research Permit \#775-1600-10 
ABSTRACT. Ocean warming linked to anthropogenic climate change is impacting the ecology of marine species around the world. In 2010, the Gulf of Maine and Scotian Shelf regions of the Northwest Atlantic underwent an unprecedented regime shift. Forced by climate-driven changes in the Gulf Stream, warm slope waters entered the region and created a less favorable foraging environment for the endangered North Atlantic right whale population. By mid-decade, right whales had shifted their late spring/summer foraging grounds from the Gulf of Maine and the western Scotian Shelf to the Gulf of St. Lawrence. The population also began exhibiting unusually high mortality in 2017. Here, we report that climate-driven changes in ocean circulation have altered the foraging environment and habitat use of right whales, reducing the population's calving rate and exposing it to greater mortality risks from ship strikes and fishing gear entanglement. The case of the North Atlantic right whale provides a cautionary tale for the management of protected species in a changing ocean.

\section{INTRODUCTION}

Ocean warming linked to anthropogenic climate change is impacting the migration and distributional patterns of many marine species around the world (Greene, 2016; Scannell et al., 2016; Frölicher et al., 2018; Smale et al., 2019). Poleward shifts in habitat use are increasingly common as species migrate from lower to higher latitudes in search of thermal refugia (Sunday et al., 2012; Pinsky et al., 2013).
Even marine species that are less sensitive to temperature may still be forced to migrate in pursuit of their prey (Sydeman et al., 2015). In an ocean undergoing rapid and occasionally abrupt warming, the management plans for protected species must be dynamic and capable of adapting on timescales comparable to the underlying changes in their ecosystems (Pinsky and Mantua, 2014; Pinsky et al., 2018).

During the past decade, the Northwest
Atlantic's Gulf of Maine and western Scotian Shelf have been warming more rapidly than most of the global ocean (Figure 1; Pershing et al., 2015; Greene, 2016; Scannell et al., 2016; Seidov et al., 2021). As this region has warmed, the North Atlantic right whale, Eubalaena glacialis, began abandoning some of its traditional foraging grounds (Pettis et al., 2020). Since 2015, increasing numbers of right whales have been observed foraging in the Gulf of St. Lawrence. Coinciding with this behavioral change, the right whale population has exhibited an unusually high mortality rate since 2017 , cumulatively losing an unprecedented number of adult whales to ship strikes and fishing gear entanglement (Pettis et al., 2021). The population also has exhibited a reduction in its calving rate since 2010 (Pettis et al., 2021). With an elevated mortality rate and depressed calving rate, the right whale population has declined by an estimated $26 \%$ this decade and now is thought to number fewer than 360 individuals (Pettis

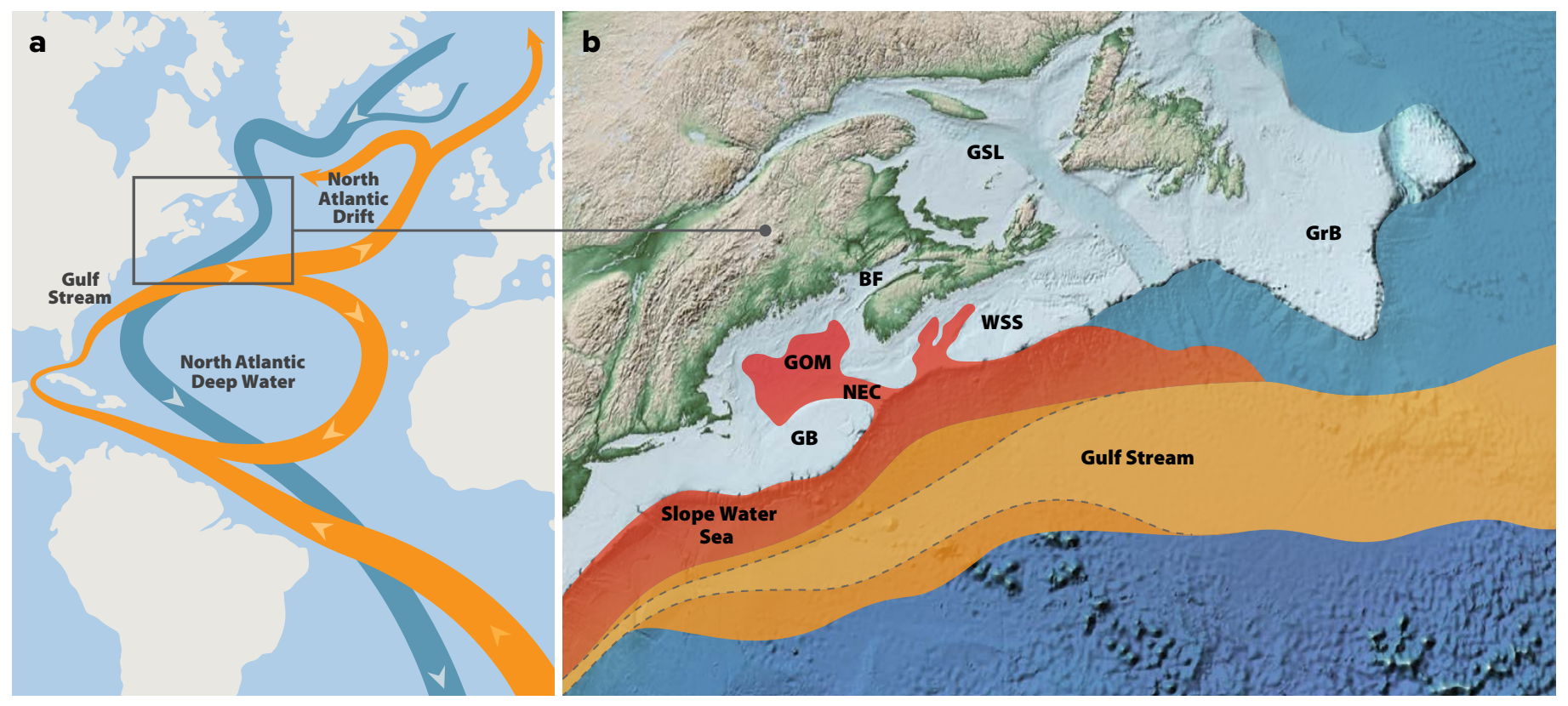

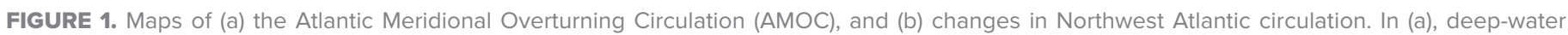

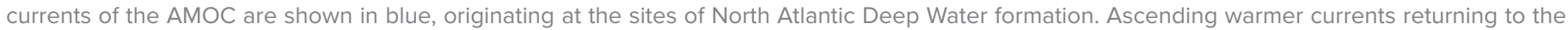

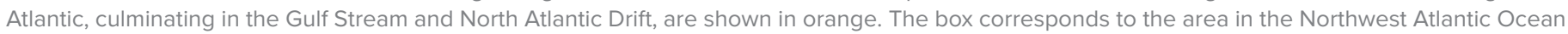

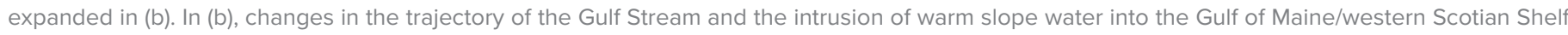

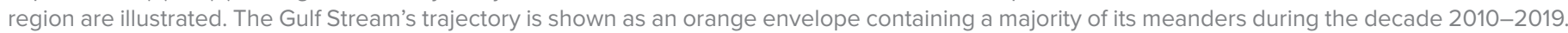

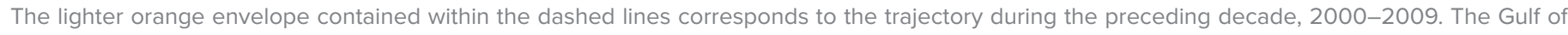

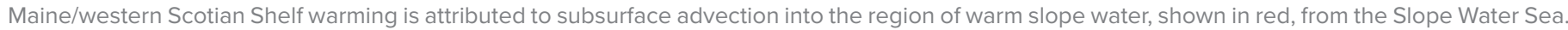


Scotian Shelf. (a) Adapted from Rahmstorf (1997) under Creative Commons BY-SA 4.0 
et al., 2021). With the population facing its greatest threat since the cessation of commercial whaling, the International Union for the Conservation of Nature changed the species' status from endangered to critically endangered in July 2020. Understanding links between the Gulf of Maine and western Scotian Shelf regions' abrupt warming and the subsequent right whale population's demographic decline is critical to managing this species' recovery.

The North Atlantic right whale population first received protected status in 1935; however, its recovery has been slow due to elevated mortality rates linked to anthropogenic sources, primarily ship strikes and entanglement in fishing gear (Kraus and Rolland, 2007; Knowlton et al., 2012; Henry et al., 2020). The population increased during the 1980s, 1990s, and the initial decade of the 2000s, the first three decades after demographic data became available (Meyer-Gutbrod and Greene, 2014; Pace et al., 2017). During this time, considerable interdecadal variability in the rate of increase was observed (Meyer-Gutbrod and Greene, 2014). This variability was linked to right whale calving rates that differed from one decade to the next in response to changing prey availability in the Gulf of Maine and western Scotian Shelf foraging grounds (Meyer-Gutbrod et al., 2015).

Older developmental stages of the lipid-rich copepod species Calanus finmarchicus are the right whale population's primary source of nutrition. Models driven by this prey species' abundance in the Gulf of Maine and western Scotian Shelf region explain a significant proportion of the right whale population's calving rate variability observed from 1980 to 2009 (Greene et al., 2003; Greene and Pershing, 2004; Meyer-Gutbrod and Greene, 2014, 2018; Meyer-Gutbrod et al., 2015). During these three decades, C. finmarchicus abundance in the region responded consistently to decadal-scale ecosystem regime shifts driven by remote climate forcing and freshwater export from the Arctic (MERCINA, 2012; Greene et al., 2013).
During the 1980s, Arctic climatic conditions favored less freshwater export from the Arctic Ocean into the Northwest Atlantic, and C. finmarchicus was abundant due to a favorable combination of high local productivity and advective supply into the Gulf of Maine and western Scotian Shelf regions from upstream sources (MERCINA, 2004). The right whale population exhibited high calving rates and a rapid rate of increase in response to high levels of prey availability (Meyer-Gutbrod and Greene, 2014, 2018).

During the 1990s, a reversal of climatic conditions in the Arctic increased freshwater export into the Northwest Atlantic, and C. finmarchicus declined in abundance as the Gulf of Maine/western Scotian Shelf ecosystem underwent a regime shift to conditions less favorable to the species' older stages (MERCINA, 2004). The right whale population exhibited relatively low calving rates and a decline in its rate of increase in response to these lower levels of prey availability (Meyer-Gutbrod and Greene, 2014, 2018).

During the initial decade of the 2000s, Arctic climatic conditions reverted back to those resembling the 1980s, freshwater export into the Northwest Atlantic declined again, and C. finmarchicus abundance rebounded (MERCINA, 2012). With this return to higher levels of prey availability, the right whale population once again exhibited relatively high calving rates and a rapid rate of increase (Meyer-Gutbrod and Greene, 2014, 2018).

The decadal-scale regime shifts observed in the Gulf of Maine and western Scotian Shelf prior to 2010 were linked to a natural mode of high-latitude climate variability, the Arctic Oscillation (MERCINA, 2012; Greene et al., 2013). The Labrador Current system mediated these downstream effects by advecting variable amounts of cooler and less saline subpolar waters southwestward into the region. In contrast, a new ecosystem regime appears to have emerged since 2010. This new regime is not a consequence of remote forcing from the Arctic. Instead, we explore the hypothesis that it is linked to the historically unprecedented warming that has been observed in the region for the past decade. Here, we analyze several long-term data sets to explore how changes in ocean circulation processes and the ecosystem have altered the foraging environment and habitat use of right whales, reducing the population's calving rate and exposing it to greater risks of serious injury and mortality from ships strikes and fishing gear entanglement.

\section{METHODS}

To explore this hypothesis, we analyzed relevant physical oceanographic and ecological data sets collected from 1980 onward, corresponding to the start of consistent right whale monitoring and data management by partners of the North Atlantic Right Whale Consortium (Meyer-Gutbrod et al., 2018; https://www.narwc.org). Such time-series analyses are essential to providing an objective, climatological context for evaluating our hypothesis. The data sets analyzed in this study are described in Table 1.

The physical and ecological data were analyzed to detect statistically significant regime shifts using the Sequential t-test Analysis of Regime Shifts (STARS) algorithm (Rodionov, 2004). Before applying the STARS algorithm, time-series data were pre-whitened using the ordinary least squares method with the MarriottPope and Kendall "MPK" correction (Rodionov, 2006). Pre-whitening was conducted to correct for autocorrelation in the time-series data. For analyses of regime shifts, a 10-year moving window $(\mathrm{L}=10)$ was applied. Regime shifts below the threshold of $\mathrm{p}=0.10$ are shown.

\section{RESULTS}

The Gulf of Maine/western Scotian Shelf region is situated in an oceanographic transition zone, one that is strongly influenced by fluctuations in the Labrador Current system to the north and the Gulf Stream to the south. The Gulf Stream's North Wall, as measured by the Gulf Stream Index (GSI; Joyce et al., 2000), 
provides a good indicator of these fluctuations. The GSI underwent a significant latitudinal shift to the north starting in 2010 (Figures 1 and 2a). Throughout the subsequent decade, the Gulf Stream's mean path has remained further north than at any time during the previous three decades.

Coincident with this decadal-scale shift in the Gulf Stream's mean path, the Gulf of Maine/western Scotian Shelf region's slope waters underwent significant warming starting in 2010, as measured by the Regional Slope Water Temperature (RSWT) Index (MERCINA, 2001; Figure 2b). Throughout the subsequent decade, the region's slope waters have remained warmer than at any time during the previous three decades. This abrupt and persistent warming is consistent with an increase in the Gulf Stream's contribution to the region's slope waters.

Coincident with the warming slope waters, the annual abundance of late-stage
C. finmarchicus copepodites in the Gulf of Maine, as measured by the C. finmarchicus Abundance Index (MERCINA, 2001), also underwent a significant decline starting in 2010 (Supplementary Materials Figure S1). The mean value of this Abundance Index during the subsequent decade was lower than during any previous decade in the time series. Because third-quarter abundances of these latestage $C$. finmarchicus copepodites in the eastern Gulf of Maine have been shown to

TABLE 1. Long-term physical and ecological data sets analyzed in this study.

\begin{tabular}{|c|c|c|}
\hline DATA SET & DESCRIPTION & REFERENCES \\
\hline $\begin{array}{l}\text { Gulf Stream } \\
\text { Index (GSI) }\end{array}$ & $\begin{array}{l}\text { The first mode derived from an empirical orthogonal function analysis of annual seawater temperatures at a } \\
\text { depth of } 200 \mathrm{~m} \text { at nine points located along the mean position of the } 15^{\circ} \mathrm{C} \text { isotherm. The GSI characterizes } \\
\text { the latitudinal position of the Gulf Stream's North Wall, with positive values corresponding to a position } \\
\text { north of the mean path, and negative values corresponding to a position south of the mean path. }\end{array}$ & $\begin{array}{l}\text { - Joyce et al., } 2000 \\
\text { - Wolfe et al., } 2019\end{array}$ \\
\hline $\begin{array}{l}\text { Regional } \\
\text { Slope Water } \\
\text { Temperature } \\
\text { (RSWT) Index }\end{array}$ & $\begin{array}{l}\text { The first mode derived from a principal components analysis of annual slope water temperature anomalies } \\
\text { collected at eight locations between } 150 \mathrm{~m} \text { and } 200 \mathrm{~m} \text { depth in the Gulf of Maine/western Scotian Shelf } \\
\text { region, including Wilkinson Basin, Jordan Basin, Georges Basin, Emerald Basin, and four sectors along the } \\
\text { inner and outer continental slope near the mouth of the Northeast Channel. The RSWT Index can be used } \\
\text { to characterize the contributions of different water masses to the region's slope waters. Positive values } \\
\text { are associated with warmer conditions, when the Gulf Stream makes a greater contribution to the region's } \\
\text { slope waters; negative values are associated with cooler conditions, when the Labrador Current system } \\
\text { makes a greater contribution to the region's slope waters. }\end{array}$ & - MERCINA, 2001 \\
\hline $\begin{array}{l}\text { C. finmarchicus } \\
\text { Abundance } \\
\text { Index }\end{array}$ & $\begin{array}{l}\text { The mean abundance anomaly for late developmental stages-fifth copepodites and adults-of this species } \\
\text { estimated from samples collected by the Gulf of Maine Continuous Plankton Recorder (CPR) survey. } \\
\text { Although the CPR only samples near-surface waters, the CPR survey data have proven to be remarkably } \\
\text { robust in revealing the spatial and temporal distributional patterns of this species in the Gulf of Maine/ } \\
\text { western Scotian Shelf region when compared to large-scale survey data derived from samples collected } \\
\text { deeper in the water column with plankton nets. Abundance anomalies for C. finmarchicus fifth copepodite } \\
\text { and adult stages are calculated relative to an annual periodic spline function fitted to C. finmarchicus } \\
\text { anomalies from the climatological mean abundances from } 1991 \text { to } 2010 \text { to account for seasonal variation. } \\
\text { The C. finmarchicus Abundance Index was resolved both seasonally and annually in this study. }\end{array}$ & $\begin{array}{l}\text { - MERCINA, } 2001 \\
\text { - Meyer-Gutbrod } \\
\text { et al., } 2015\end{array}$ \\
\hline $\begin{array}{l}\text { Right Whale } \\
\text { Calving Index }\end{array}$ & $\begin{array}{l}\text { The number of observed calf births divided by the number of reproductively available females each year. } \\
\text { Reproductively available females include those that are at least nine years of age or have given birth to } \\
\text { calves previously and have not given birth during the previous two years. }\end{array}$ & $\begin{array}{l}\text { - North Atlantic } \\
\text { Right Whale } \\
\text { Consortium, } 2018\end{array}$ \\
\hline $\begin{array}{l}\text { Right Whale } \\
\text { Sightings Per } \\
\text { Unit Effort } \\
\text { (SPUE) }\end{array}$ & $\begin{array}{l}\text { The number of sightings made divided by the effort expended to collect the sightings. Effort is measured } \\
\text { as the number of kilometers transited by a survey vessel or aircraft while making visual observations. In } \\
\text { this study, SPUE is aggregated across geographic polygons corresponding to major known right whale } \\
\text { foraging habitats: Cape Cod Bay, Great South Channel, Roseway Basin, Bay of Fundy, and southern Gulf } \\
\text { of St. Lawrence (Figures 3, S3, S4). Within each polygon, SPUE was aggregated into two decadal time } \\
\text { periods, 2000-2009 and 2010-2019, to demonstrate the difference in right whale foraging habitat use } \\
\text { between the two decades. Right whale survey effort is not consistent across space or time, and therefore } \\
\text { SPUE data are biased with more effort exerted in areas where researchers expect whales to occur. Effort } \\
\text { can also be limited by funding, weather, and accessibility, contributing to this bias. }\end{array}$ & \\
\hline $\begin{array}{l}\text { Number of } \\
\text { Observed } \\
\text { Right Whale } \\
\text { Calves }\end{array}$ & $\begin{array}{l}\text { The number of calves reported each year in the sightings data from the North Atlantic Right Whale } \\
\text { Consortium photo identification database. Because most calf births occur during December, January, and } \\
\text { February, births are grouped according to the "right whale year" beginning in December of the previous } \\
\text { calendar year. }\end{array}$ & $\begin{array}{l}\text { North Atlantic } \\
\text { Right Whale } \\
\text { Consortium, } 2018\end{array}$ \\
\hline $\begin{array}{l}\text { Number of } \\
\text { Observed } \\
\text { Right Whale } \\
\text { Carcasses }\end{array}$ & $\begin{array}{l}\text { The number of carcasses reported each year in the sightings data of the North Atlantic Right Whale } \\
\text { Consortium photo identification database. Only the first sighting of each carcass is included in the time } \\
\text { series. These data reflect only observed mortalities and are a minimal estimate of the total number of } \\
\text { mortalities in a given year. Many mortalities are presumed and recorded only after individuals have not } \\
\text { been sighted for five or more consecutive years. Because these presumed mortalities cannot be dated by } \\
\text { year, they have not been included in this time series. }\end{array}$ & $\begin{array}{l}\text { - North Atlantic } \\
\text { Right Whale } \\
\text { Consortium, } 2018\end{array}$ \\
\hline
\end{tabular}


be the most relevant in determining the probability of successful right whale pregnancies (Meyer-Gutbrod et al., 2015), that time series is presented in Figures 2c and S2.

The right whale population exhibited demographic changes consistent with a regime shift that resulted in a less favorable foraging environment. Coincident with the decline in prey availability, annual right whale calf recruitment declined significantly
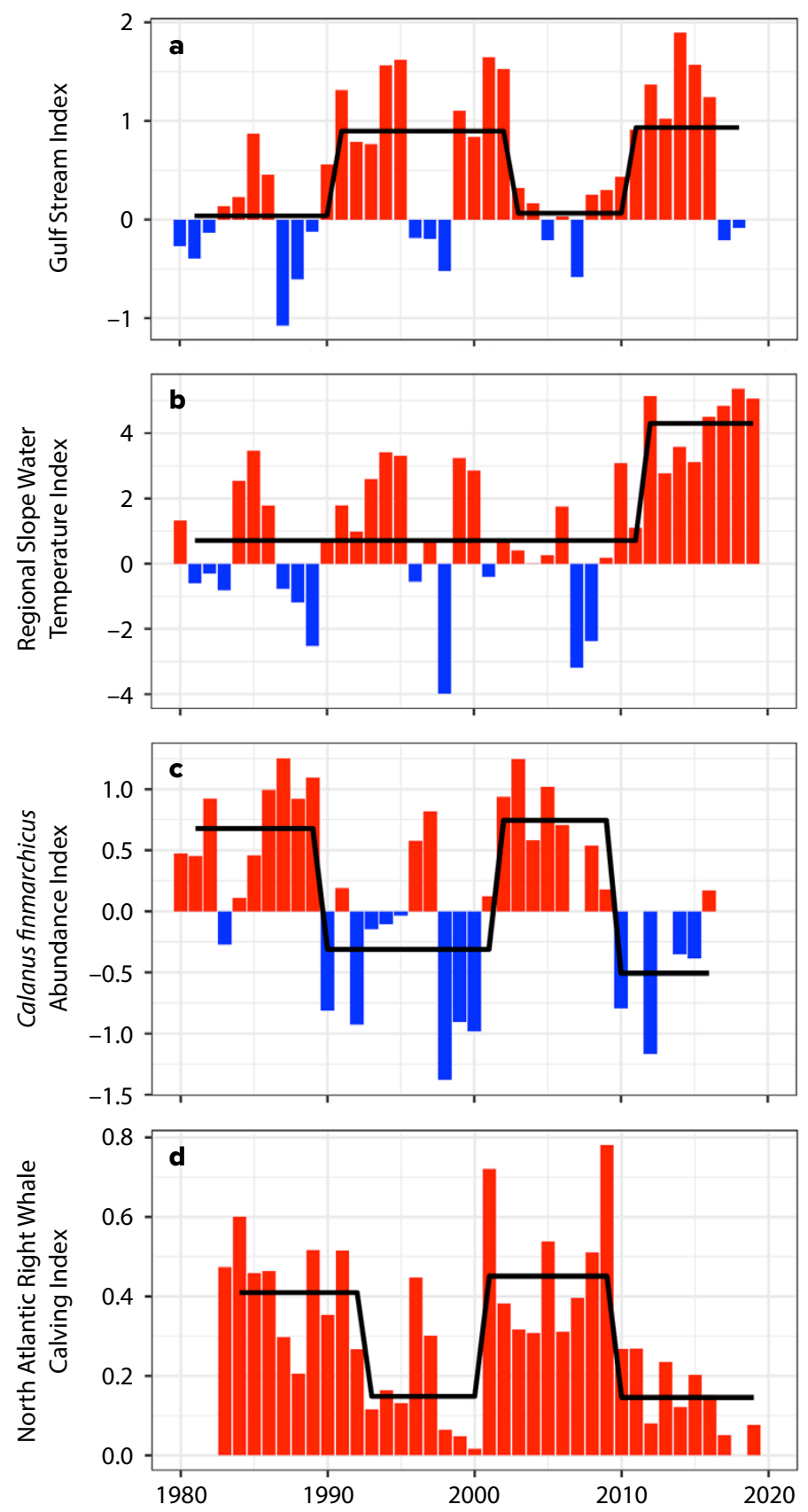

FIGURE 2. Time series of (a) the Gulf Stream Index, (b) the Regional Slope Water Temperature Index, (c) the summertime (third quarter-July, August, September) eastern Gulf of Maine C. finmarchicus Abundance Index, and (d) the Right Whale Calving Index. Positive index values are shown in red, negative values in blue. Black solid lines indicate regime shifts in the time series detected using the Sequential t-test Analysis of Regime Shifts (STARS) algorithm. starting in 2010 (Figure 2d). Of adult females available to reproduce, the percentage that gave birth averaged just $15 \%$ each year during the decade of 2010-2019, compared to $47 \%$ during the preceding decade.

Sightings data analyzed from the North Atlantic Right Whale Consortium database reveal that the use of certain foraging grounds changed after the 2010 regime shift (Figures 3 and S3). Right whale sightings per unit effort (SPUE) declined during the subsequent decade on the traditional foraging grounds found in the Great South Channel, Bay of Fundy, and Roseway Basin during the summer and autumn. In contrast, a portion of the right whale population began using the southern Gulf of St. Lawrence as a late spring to autumn foraging ground after 2015 (Figure 3; Simard et al., 2019). Right whale SPUE also increased in Cape Cod Bay during autumn, winter, and spring after the regime shift. Note that right whale SPUE data should be interpreted cautiously because effort is not distributed uniformly across either time or space, and animal behavior impacts sighting availability (Ganley et al., 2019). Nevertheless, effort is typically high in habitats and seasons in which right whales have been observed in high abundance historically (see 1,000 km threshold in Figure 3).

Two spikes in the annual number of observed right whale carcasses occurred during 2017 and 2019 (Figure 4). These spikes above background levels, with 17 carcasses discovered in 2017 and 10 in 2019, were driven by anthropogenic sources of mortality in the southern Gulf of St. Lawrence after a portion of the right whale population shifted its late spring/summer foraging effort there.

\section{DISCUSSION}

The analyses of long-term data sets reported here provide evidence supporting the hypothesis that a climate-driven regime shift in the Gulf of Maine/western Scotian Shelf region occurred in 2010 and impacted the foraging environment, habitat use, and demography of the right whale population. Our findings are consistent with results from several recent studies (MeyerGutbrod and Greene, 2018; Record et al., 2019; Sorochan et al., 2019), and when the insights from all of them are combined, a more complete picture comes into view of the physical and ecological processes involved.

In 2010, a new physical oceanographic regime emerged in the Gulf of Maine/western Scotian Shelf region. This new regime is linked to the advection of warm slope water into the region and may be associated with a weakening of the Atlantic meridional overturning circulation (AMOC; Figure 1a,b). The AMOC has been weakening since the mid-twentieth century (Rhamstorf et al., 2015), a process indicated by the characteristic sea surface temperature "fingerprint" of cooling in the subpolar North Atlantic and warming in the Gulf Stream region of the Northwest Atlantic (Caesar et al., 2018). Although natural climate variability cannot be ruled out at this time, these 
observations are consistent with recent, high-resolution ocean circulation models that predict enhanced warming of the Northwest Atlantic in response to anthropogenic climate change (Saba et al., 2016). Consistent with model predictions, the Gulf Stream has weakened, and its north wall has shifted to a more northerly position (Figures $1 \mathrm{~b}$ and $2 \mathrm{a}$ ). In addition, the geographic location of the Gulf Steam's destabilization point, where it transitions from a narrow jet to a widely meandering current, has shifted westward by $\sim 25 \mathrm{~km}$ per year (Figure 1b; Andres, 2016), and there has been a significant increase in the number of warm core rings generated since 2000 (Gawarkiewicz et al., 2018). Each of these changes in the Gulf Stream can have important implications for the slope and shelf waters of the Northwest Atlantic.

The Slope Water Sea, situated between the continental shelf and Gulf Stream after it detaches from the shelf north of Cape Hatteras (Figure 1b), is the primary mixing zone where slope waters derived from the Gulf Stream and the Labrador Current system intermingle (MERCINA, 2001). Multiple processes contribute to increased heat content in the Slope Water Sea and adjacent shelf waters. Heat flux from the atmosphere can lead to the development of marine heatwaves in the surface waters (Chen et al., 2015; Schlegel et al., 2021), and Gulf Stream warm core rings can intrude onto the shelf in the Mid-Atlantic Bight and Georges Bank regions (Gawarkiewicz et al., 2018). However, the recent, decade-long warming event observed in the Gulf of Maine/ western Scotian Shelf slope water can be attributed primarily to the subsurface advection of slope water comprising a relatively large component of Gulf Stream water and a relatively small component of Labrador Current water (Figure 1b; Jutras et al., 2020; Neto et al. 2021; Seidov et al., 2021). These warmer and more saline slope water intrusions enter the deep basins and troughs of the Gulf of Maine and the western Scotian Shelf through various deep-water channels,


Number of whale icons $\rightarrow$ Mean SPUE category

$0 \rightarrow 0.0 \leq$ SPUE $<0.5$ per $100 \mathrm{~km} \quad 4 \rightarrow 7.5 \leq$ SPUE $<10.0$ per $100 \mathrm{~km}$

$1 \rightarrow 0.5 \leq$ SPUE $<2.5$ per $100 \mathrm{~km} \quad 5 \rightarrow 10.0 \leq$ SPUE $<12.5$ per $100 \mathrm{~km}$

$2 \rightarrow 2.5 \leq$ SPUE $<5.0$ per $100 \mathrm{~km} \quad 6 \rightarrow 12.5 \leq$ SPUE $<15.0$ per $100 \mathrm{~km}$

$3 \rightarrow 5.0 \leq$ SPUE $<7.5$ per $100 \mathrm{~km}$

FIGURE 3. Quarterly right whale sightings per unit effort (SPUE) for five key foraging grounds during the two decades of interest, 2000-2009 and 2010-2019. Each column corresponds to a decade; each row corresponds to a seasonal quarter (Q1 = January, February, March; Q2 = April, May, June; Q3 = July, August, September; Q4 = October, November, December). In each map, circles correspond to the five major right whale foraging grounds: Cape Cod Bay (CCB), Great South Channel (GSC), Bay of Fundy (BOF), Roseway Basin (RB), and southern Gulf of St. Lawrence (sGSL). The number of whale icons in each foraging ground circle corresponds to the mean SPUE category, as defined in the key, observed for that quarter and decade. Circles drawn with a dashed line indicate low survey effort $(<1,000 \mathrm{~km})$. Circle and icon colors during the second decade indicate a decline (red), increase (green), or no change (black circles, white whale icons) in mean SPUE from the previous decade. 


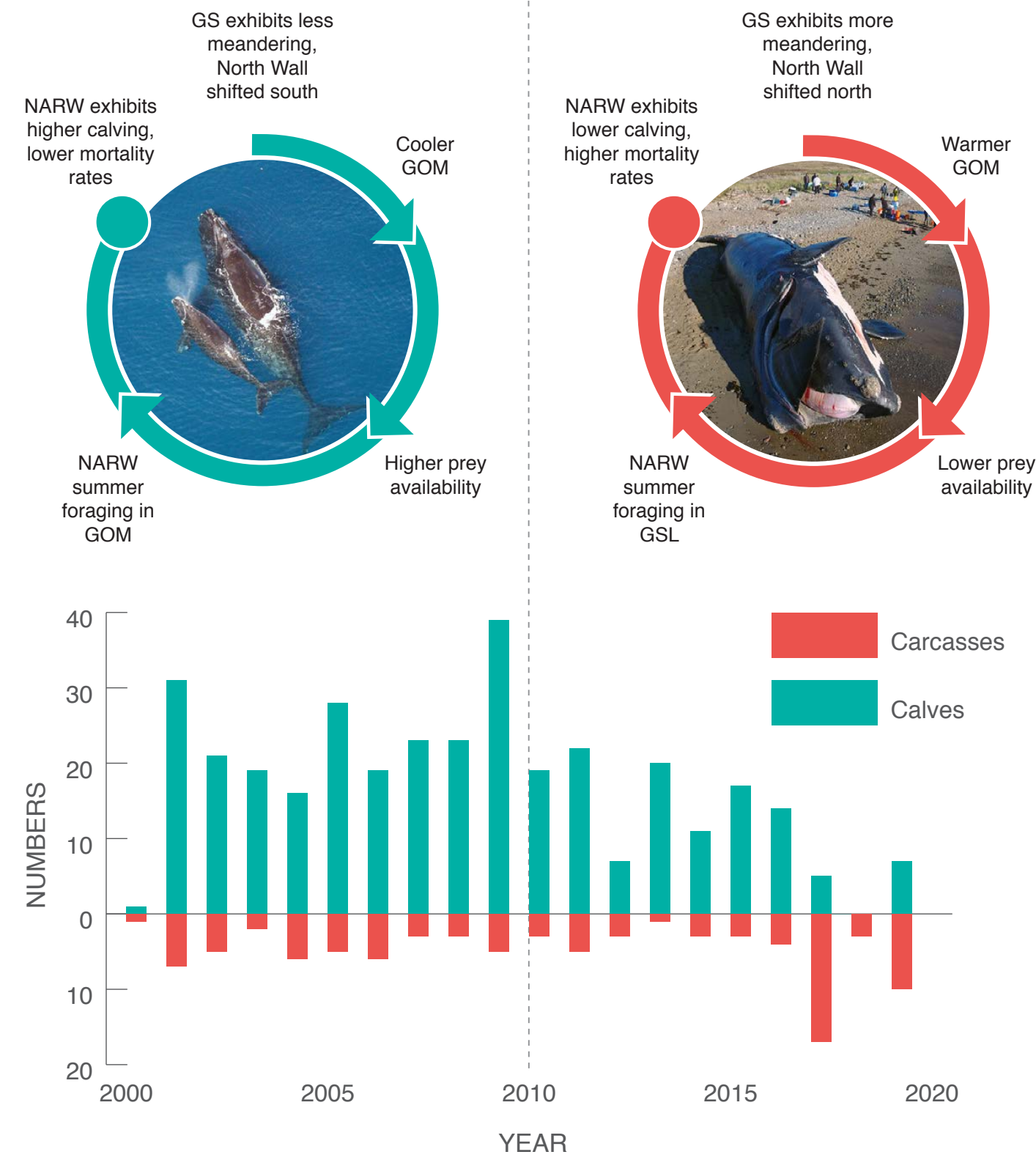

Prior to 2010 Doubling Time: LESS THAN TWO DECADES

After 2017 Time to Extinction: LESS THAN A CENTURY

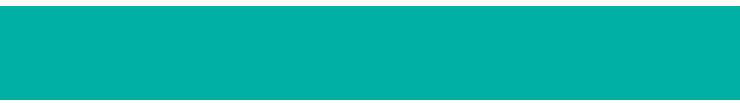

Low

Moderate

High

\section{EXTINCTION RISK}

FIGURE 4. Infographic reviewing the impacts of changing ocean conditions on the right whale population during 2000-2009 (left) and 2010-2019 (right). Time series of observed numbers of right whale calves (green) and carcasses (red) observed each year. Extinction risk was low during 2000 to 2009, when ocean conditions were favorable, calving rates were relatively high, and mortality rates were relatively low. Extinction risk became moderate from 2010 to 2016, when ocean conditions were less favorable, calving rates declined, and many whales were not observed during surveys. Extinction risk became high in 2017 when ocean conditions remained less favorable, calving rates remained relatively low, and an unusual mortality event was initiated. GOM = Gulf of Maine. GS = Gulf Stream. GSL = Gulf of St. Lawrence. NARW = North Atlantic right whale. 
with the Northeast Channel being the most prominent (Figure 1b; Saba et al., 2016; Sorochan et al., 2019). The 2010 regime shift and subsequent rising trends in the RSWT Index (Figure 2b) and regional salinities (Sorochan et al., 2019) provide strong evidence consistent with this interpretation.

Coinciding with the regime shift in 2010, annual C. finmarchicus abundance declined significantly in the Gulf of Maine and has remained anomalously low (Figure S1; Record et al., 2019; Sorochan et al., 2019). This decline is likely due to a combination of reduced advective supply of this species into the region and an increase in deep-water temperatures. While the elevated temperatures are not sufficient to cause mortality directly, they can impact the C. finmarchicus population negatively by increasing metabolic rates and curtailing the duration of this species' diapause period, potentially exposing it to greater predation risk or reduced overwintering survivorship (Record et al., 2019). Although locally enhanced productivity has supported elevated abundances of $C$. finmarchicus in the western Gulf of Maine (Ji et al., 2017), the population has declined significantly in the eastern Gulf of Maine during the third quarter summer months (Figure 2c). This decline has had far-reaching consequences for the right whale population.

Troubling signs for the right whale population began to emerge after the 2010 regime shift and decline in C. finmarchicus abundance. In contrast to the record high 39 calves born during 2009, right whale calving rates dropped significantly beginning in 2010 (Figure 2d). During the summer of 2012, C. finmarchicus abundance in the eastern Gulf of Maine fell below a previously estimated prey availability threshold found to trigger prenatal or neonatal calf mortality due to inadequate nutrition (Figure S2; MeyerGutbrod et al., 2015). For most of the decade, the calving rate remained comparable to that observed during the 1990s, a previous decade of low C. finmarchicus abundance in the region (Figure 2c,d).

Also beginning in 2010, the number of right whales returning to the species' traditional summertime foraging grounds in the eastern Gulf of Maine and the Bay of Fundy declined rapidly (Figure 3; Davies and Brillant, 2019; Davies et al., 2019; Record et al., 2019). Despite considerable survey effort, the whereabouts of the majority of the population during the foraging seasons of 2010-2014 are largely unknown; however, sporadic sightings and acoustic detections in Canadian waters suggest a dispersed distribution (Davies et al., 2019). Acoustic monitoring revealed a significant increase in the presence of whales in the southern Gulf of St. Lawrence beginning in 2015 (Simard et al., 2019). A visual monitoring program was implemented in the region during 2015, and it revealed a relatively large number of whales foraging in the southern Gulf of St. Lawrence during that year and subsequent years (Figure 3; Davies and Brillant, 2019). Because right whales spend the majority of their time during the summer season foraging (Goodyear, 1996; Parks et al., 2011), this distribution shift is likely motivated by a search for higher prey availability.

As right whale numbers visiting the southern Gulf of St. Lawrence foraging grounds rose, the risks associated with ship strikes and entanglement increased (Figure 4). With no management plan in place to protect it, the right whale population experienced an increasing number of serious entanglements and mortalities in the southern Gulf of St. Lawrence beginning in 2015 (Figure 4; Davies and Brillant, 2019). During the summer of 2017, the US National Marine Fisheries Service declared an unusual mortality event when 17 dead right whale carcasses were discovered, 12 of them in the southern Gulf of St. Lawrence and five in US waters (Meyer-Gutbrod et al., 2018; Davies and Brillant, 2019; Pettis et al., 2020). Ship strikes and fishing gear entanglement were the only sources of mortality for carcasses in which the cause of death could be determined (Pettis et al., 2020).
In response to this unusual mortality event, the Canadian federal government collaborated with many provincial and nongovernmental organizations to implement a crisis management plan to protect right whales (Davies and Brillant, 2019). This plan appeared successful, reducing right whale mortalities to zero in the southern Gulf of St. Lawrence and three overall during 2018 (Figure 4; Davies and Brillant, 2019; Pettis et al., 2020). However, the management plan proved ineffective the following year when 10 right whale deaths occurred during the summer of 2019 (Figure 4; Pettis et al., 2020). The unusual mortality event has contributed to an observed cumulative loss of $\sim 7 \%$ of the total population during the past three years. After factoring in model-estimated latent mortality, the true right whale population loss from the start of 2017 to the end of 2019 may be closer to $17 \%$ (Pettis et al., 2021; Pace et al., 2021). This is the first multiyear decline observed in the right whale population since post-whaling demographic data became available during the early 1980s.

\section{Management Implications}

The case of the North Atlantic right whale population provides a cautionary tale for the management of protected species in a changing ocean (Pinsky and Mantua, 2014; Meyer-Gutbrod et al., 2018; Pinsky et al., 2018; Davies and Brillant, 2019). As anthropogenic climate warming emerges from a background of natural climate variability, ecosystem regimes will shift, and species ranges will both contract and expand (Greene, 2016). Rising global temperatures are causing poleward shifts in distributions already, yet most of our management policies are geographically rigid and lack the flexibility to respond to such shifts (Pinsky and Mantua, 2014; Meyer-Gutbrod et al., 2018; Pinsky et al., 2018; Davies and Brillant, 2019).

For the right whale population, it was anticipated that the species would seek out new foraging grounds to the north as C. finmarchicus abundance declined near 
its southern range limit (Reygondeau and Beaugrand, 2011; Greene, 2016). The summertime decline of $C$. finmarchicus in the eastern Gulf of Maine and the Bay of Fundy came about more rapidly than expected, likely due to the intensity and duration of the regional warming. As more right whales appeared in the southern Gulf of St. Lawrence, conflicts with the fishing and shipping industries seemed inevitable (Davies and Brillant, 2019). However, it was only when a crisis arose, after many whales were killed during the summer of 2017, that the Canadian government responded to the situation and implemented a management plan. That plan coincided with an elimination of mortalities in the southern Gulf of St. Lawrence during the summer of 2018. However, it failed to protect whales effectively the following summer, likely because scientists and managers lacked a sufficient understanding of the population's behavioral responses to further changes in ocean conditions within the southern Gulf of St. Lawrence. Ironically, birth rates remained low following the shift to summer foraging in the Gulf of St. Lawrence (Figure 2d), indicating that this habitat may not have adequate prey to support successful reproduction (Gavrilchuk et al., 2021).

Climate-driven advection of different water masses into the Gulf of Maine/western Scotian Shelf region has impacted the recovery rate of the right whale population every decade since the early 1980s (Meyer-Gutbrod and Greene, 2018; Davies et al., 2019). Anticipating that similar processes will continue to unfold in the future, federal agencies in Canada and the United States will need to adopt more dynamic management plans, ones that utilize continuous monitoring of relevant ocean conditions and whale sightings to inform models that can forecast right whale habitat use. Historical whaling records and modern habitat suitability models may also be useful tools for identifying emerging high-use areas. Such habitat-use forecasts are only in their early stages of development at present. However, as their forecasting skills improve, they will eventually be able to provide a basis for regulating shipping, fisheries closures, and gear restrictions when whales are expected to be present. Failure to adopt such measures and significantly reduce anthropogenic mortality sources could commit the right whale population to extinction before the end of the century (Figure 4; Supplementary Materials). @

\section{SUPPLEMENTARY MATERIALS}

The supplementary materials are available online at https://doi.org/10.5670/oceanog.2021.308.

\section{DATA AVAILABILITY}

Quality-checked Continuous Plankton Recorder data are available from the Marine Biological Association of the United Kingdom. Access to data can be found at https://www.cprsurvey.org/data/our-data/. Right whale population data are available from the North Atlantic Right Whale Consortium. Access to these data can be found at https://www.narwc.org/ accessing-narwc-data.html.

\section{REFERENCES}

Andres, M. 2016. On the recent destabilization of the Gulf Stream path downstream of Cape Hatteras. Geophysical Research Letters 43:9,836-9,842, https://doi.org/10.1002/2016GL069966.

Caesar, L., S. Rahmstorf, A. Robinson, G. Feulner, and V. Saba. 2018. Observed fingerprint of a weakening Atlantic Ocean overturning circulation. Nature 556(7700):191-196, https://doi.org/10.1038/ s41586-018-0006-5.

Chen, K., G. Gawarkiewicz, Y.O. Kwon, and W.G. Zhang. 2015. The role of atmospheric forcing versus ocean advection during the extreme warming of the Northeast US continental shelf in 2012. Journal of Geophysical Research: Oceans 120(6):4,324-4,339, https://doi.org/ 10.1002/2014JC010547.

Davies, K.T., and S.W. Brillant. 2019. Mass humancaused mortality spurs federal action to protect endangered North Atlantic right whales in Canada. Marine Policy 104:157-162, https://doi.org/10.1016/ j.marpol.2019.02.019.

Davies, K.T., M.W. Brown, P.K. Hamilton, A.R. Knowlton, C.T. Taggart, and A.S. Vanderlaan. 2019. Variation in North Atlantic right whale Eubalaena glacialis occurrence in the Bay of Fundy, Canada, over three decades. Endangered Species Research 39:159-171, https://doi.org/10.3354/ esr00951.

Frölicher, T.L., E.M. Fischer, and N. Gruber. 2018. Marine heatwaves under global warming. Nature 560:360-364, https://doi.org/10.1038/ s41586-018-0383-9.

Ganley, L.C., S. Brault, and C.A. Mayo. 2019. What we see is not what there is: Estimating North Atlantic right whale Eubalaena glacialis local abundance. Endangered Species Research 38:101-113, https://doi.org/10.3354/esr00938.

Gavrilchuk, K., V. Lesage, S.M. Fortune, A.W. Trites, and S. Plourde. 2021. Foraging habitat of North Atlantic right whales has declined in the Gulf of St. Lawrence, Canada, and may be insufficient for successful reproduction. Endangered Species Research 44:113-136, https://doi.org/10.3354/ esr01097.
Gawarkiewicz, G., R.E. Todd, W. Zhang, J. Partida, A. Gangopadhyay, M.-U.-H. Monim, P. Fratantoni, A. Malek Mercer, and M. Dent. 2018. The changing nature of shelf-break exchange revealed by the OOI Pioneer Array. Oceanography 31(1):60-70, https://doi.org/10.5670/oceanog.2018.110.

Goodyear, J.D. 1996. Significance of Feeding Habitats of North Atlantic Right Whales Based on Studies of Diel Behaviour, Diving, Food Ingestion Rates, and Prey. PhD Dissertation, Guelph University.

Greene, C.H., A.J. Pershing, R.D. Kenney, and J.W. Jossi. 2003. Impact of climate variability on the recovery of endangered North Atlantic right whales. Oceanography 16(4):98-103, https://doi.org/10.5670/oceanog.2003.16.

Greene, C.H., and A.J. Pershing. 2004. Climate and the conservation biology of North Atlantic right whales: The right whale at the wrong time? Frontiers in Ecology and the Environment 2(1):29-34, https://doi.org/10.1890/ 1540-9295(2004)002[0029:CATCBO]2.0.CO;2.

Greene, C.H., E. Meyer-Gutbrod, B.C. Monger, L.P. McGarry, A.J. Pershing, I.M. Belkin, P.S. Fratantoni, D.G. Mountain, R.S. Pickart, A. Proshutinsky, and others. 2013. Remote climate forcing of decadal-scale regime shifts in Northwest Atlantic shelf ecosystems. Limnology and Oceanography 58(3):803-816, https://doi.org/ 10.4319/lo.2013.58.3.0803.

Greene, C.H. 2016. North America's iconic marine species at risk due to unprecedented ocean warming. Oceanography 29(3):14-17, https://doi.org/ 10.5670/oceanog.2016.67.

Henry, A.G., M. Garron, D. Morin, A. Reid, W. Ledwell, and T.V.N. Cole. 2020. Serious Injury and Mortality Determinations for Baleen Whale Stocks along the Gulf of Mexico, United States East Coast, and Atlantic Canadian Provinces, 2013-2017. US Department of Commerce, Northeast Fisheries Science Center Reference Document 20-06, 53 pp., https://repository.library.noaa.gov/view/ noaa/25359.

Ji, R., Z. Feng, B.T. Jones, C. Thompson, C. Chen, N.R. Record, and J.A. Runge. 2017. Coastal amplification of supply and transport (CAST): A new hypothesis about the persistence of Calanus finmarchicus in the Gulf of Maine. ICES Journal of Marine Science 74(7):1,865-1,874, https://doi.org/ 10.1093/icesjms/fsw253.

Joyce, T.M., C. Deser, and M.A. Spall. 2000. The relation between decadal variability of subtropical mode water and the North Atlantic Oscillation. Journal of Climate 13:2,550-2,569, https://doi.org/ 10.1175/1520-0442(2000)013<2550:TRBDVO> 2.0.CO;2.

Jutras, M., C.O. Dufour, A. Mucci, F. Cyr, and D. Gilbert 2020. Temporal changes in the causes of the observed oxygen decline in the St. Lawrence Estuary. Journal of Geophysical Research: Oceans 125(12):e2020JC016577, https://doi.org/ 10.1029/2020JC016577.

Knowlton, A.R., P.K. Hamilton, M.K. Marx, H.M. Pettis, and S.D. Kraus. 2012. Monitoring North Atlantic right whale Eubalaena glacialis entanglement rates: A 30 yr retrospective. Marine Ecology Progress Series 466:293-302, https://doi.org/10.3354/ meps09923.

Kraus, S.D., and R. Rolland, eds. 2007. The Urban Whale: North Atlantic Right Whales at the Crossroads. Harvard University Press, Cambridge, MA, $576 \mathrm{pp}$

MERCINA (Marine Ecosystem Responses to Climate in the North Atlantic). 2001. Oceanographic responses to climate in the Northwest Atlantic. Oceanography 14(3):76-82, https://doi.org/10.5670/ oceanog.2001.25. 
MERCINA. 2004. Supply-side ecology and the response of zooplankton to climate-driven changes in the North Atlantic Ocean.

Oceanography 17(3):60-71, https://doi.org/10.5670/ oceanog.2004.31.

MERCINA. 2012. Recent Arctic climate change and its remote forcing of Northwest Atlantic shelf ecosystems. Oceanography 25(3):208-213, https://doi.org/10.5670/oceanog.2012.64.

Meyer-Gutbrod, E.L., and C.H. Greene. 2014 Climate-associated regime shifts drive decadalscale variability in recovery of North Atlantic right whale population. Oceanography 27(3):148-153, http://doi.org/10.5670/oceanog.2014.64.

Meyer-Gutbrod, E.L., C.H. Greene, P.J. Sullivan, and A.J. Pershing. 2015. Climate-associated changes in prey availability drive reproductive dynamics of the North Atlantic right whale population. Marine Ecology Progress Series 535:243-258, https://doi.org/10.3354/meps11372.

Meyer-Gutbrod, E.L., and C.H. Greene. 2018. Uncertain recovery of the North Atlantic right whale in a changing ocean. Global Change Biology 24:455-464, https://doi.org/10.1111/ gcb.13929.

Meyer-Gutbrod, E.L., C.H. Greene, and K.T.A. Davies. 2018. Marine species range shifts necessitate advanced policy planning: The case of the North Atlantic right whale. Oceanography 31(2):19-23, https://doi.org/10.5670/oceanog.2018.209.

Neto, A.G., J.A. Langan, and J.B. Palter. 2021 Changes in the Gulf Stream preceded rapid warming of the Northwest Atlantic Shelf. Communications Earth \& Environment 2(1):74, https://doi.org/10.1038/s43247-021-00143-5.

North Atlantic Right Whale Consortium. 2018. North Atlantic Right Whale Consortium Sightings and Identification Databases. New England Aquarium, Boston, MA, https://www.narwc.org/narwcdatabases.html.

Pace, R.M. III, P.J. Corkeron, and S.D. Kraus. 2017. State-space mark-recapture estimates reveal a recent decline in abundance of North Atlantic right whales. Ecology and Evolution 7(21):8,730-8,741, https://doi.org/10.1002/ece3.3406.

Pace, R.M. III, R. Williams, S.D. Kraus, A.R. Knowlton, and H.M. Pettis. 2021. Cryptic mortality of North Atlantic right whales. Conservation Science and Practice 3(2):e346, https://doi.org/10.1111/csp2.346.

Parks, S.E., A. Searby, A. Célérier, M.P. Johnson, D.P. Nowacek, and P.L. Tyack. 2011. Sound production behavior of individual North Atlantic right whales: Implications for passive acoustic monitoring. Endangered Species Research 15(1):63-76, https://doi.org/10.3354/esr00368.

Pershing, A.J., M.A. Alexander, C.M. Hernandez, L.A. Kerr, A. Le Bris, K.E. Mills, J.A. Nye, N.R. Record, H.A. Scannell, J.D. Scott, and G.D. Sherwood. 2015. Slow adaptation in the face of rapid warming leads to collapse of the Gulf of Maine cod fishery. Science 350(6262):809-812, https://doi.org/ 10.1126/science.aac9819.

Pettis, H.M., R.M. Pace III, and P.K. Hamilton. 2020. North Atlantic Right Whale Consortium 2019 annual report card. North Atlantic Right Whale Consortium, Boston, MA, https://www.narwc.org/ report-cards.html.

Pettis, H.M., R.M. Pace III, and P.K. Hamilton. 2021. North Atlantic Right Whale Consortium 2020 annual report card. North Atlantic Right Whale Consortium, Boston, MA, https://www.narwc.org/ report-cards.html.

Pinsky, M.L., B. Worm, M.J. Fogarty, J.L. Sarmiento, and S.A. Levin. 2013. Marine taxa track local climate velocities. Science 341(6151):1,239-1,242, https://doi.org/10.1126/science.1239352.
Pinsky, M.L., and N.J. Mantua. 2014. Emerging adaptation approaches for climate-ready fisheries management. Oceanography 27(4):146-159, https://doi.org/10.5670/oceanog.2014.93.

Pinsky, M.L., G. Reygondeau, R. Caddell, J. PalaciosAbrantes, J. Spijkers, and W.W. Cheung. 2018. Preparing ocean governance for species on the move. Science 360:1,189-1,191, https://doi.org/ 10.1126/science.aat2360

Rahmstorf, S. 1997. Risk of sea-change in the Atlantic. Nature 388:825-826, https://doi.org/10.1038/42127.

Rahmstorf, S., J.E. Box, G. Feulner, M.E. Mann, A. Robinson, S. Rutherford, and E.J. Schaffernicht. 2015. Exceptional twentieth-century slowdown in Atlantic Ocean overturning circulation. Nature Climate Change 5(5):475-480, https://doi.org/ 10.1038/nclimate2554.

Record, N.R., J.A. Runge, D.E. Pendleton, W.M. Balch, K.T.A. Davies, A.J. Pershing, C.L. Johnson, K. Stamieszkin, R. Ji, Z. Feng, and others. 2019. Rapid climate-driven circulation changes threaten conservation of endangered North Atlantic right whales. Oceanography 32(2):162-169, https://doi.org/10.5670/oceanog.2019.201.

Reygondeau, G., and G. Beaugrand. 2011. Future climate-driven shifts in distribution of Calanus finmarchicus. Global Change Biology 17(2):756-766, https://doi.org/10.1111/j.1365-2486.2010.02310.x.

Rodionov, S.N. 2004. A sequential algorithm for testing climate regime shifts. Geophysical Research Letters 31(9), https://doi.org/ 10.1029/2004GL019448.

Rodionov, S.N. 2006. Use of pre-whitening in climate regime shift detection. Geophysical Research Letters 33(12), https://doi.org/10.1029/ 2006 GL025904.

Saba, V.S., S.M. Griffies, W.G. Anderson, M. Winton, M.A. Alexander, T.L. Delworth, J.A. Hare, M.J. Harrison, A. Rosati, G.A. Vecchi, and R. Zhang. 2016. Enhanced warming of the Northwest Atlantic Ocean under climate change. Journal of Geophysical Research 121(1):118-132, https://doi.org/10.1002/2015JC011346.

Scannell, H.A., A.J. Pershing, M.A. Alexander A.C. Thomas, and K.E. Mills. 2016. Frequency of marine heatwaves in the North Atlantic and North Pacific since 1950. Geophysical Research Letters 43:2,069-2,076, https://doi.org/10.1002/ 2015GL067308.

Schlegel, R.W., E.C. Oliver, and K. Chen. 2021. Drivers of marine heatwaves in the Northwest Atlantic: The role of air-sea interaction during onset and decline. Frontiers in Marine Science 8:627970, https://doi.org/10.3389/fmars.2021.627970.

Seidov, D., A. Mishonov, and R. Parsons. 2021. Recent warming and decadal variability of Gulf of Maine and slope water. Limnnology and Oceanography, https://doi.org/10.1002/Ino.11892.

Simard, Y., N. Roy, S. Giard, and F. Aulanier. 2019 North Atlantic right whale shift to the Gulf of St. Lawrence in 2015, revealed by longterm passive acoustics. Endangered Species Research 40:271-284, https://doi.org/10.3354/ esr01005.

Sorochan, K.A., S. Plourde, R. Morse, P. Pepin, J. Runge, C. Thompson, and C.L. Johnson. 2019 North Atlantic right whale (Eubalaena glacialis) and its food: Part II. Interannual variations in biomass of Calanus spp. on western North Atlantic shelves. Journal of Plankton Research 41:687-708 https://doi.org/10.1093/plankt/fbz044.

Smale, D.A., T. Wernberg, E.C.J. Oliver, M. Thomsen, B.P. Harvey, S.C. Straub, M.T. Burrows, L.V. Alexander, J.A. Benthuysen, M.G. Donat, and others. 2019. Marine heatwaves threaten global biodiversity and the provision of ecosystem services. Nature Climate Change 9:306-312, https://doi.org/10.1038/s41558-019-0412-1.
Sunday, J.M., A.E. Bates, and N.K. Dulvy. 2012. Thermal tolerance and the global redistribution of animals. Nature Climate Change 2:686-690, https://doi.org/10.1038/nclimate1539.

Sydeman, W.J., E. Poloczanska, T.E. Reed, and S.A. Thompson. 2015. Climate change and marine vertebrates. Science 350:772-777, https://doi.org/ 10.1126/science.aac9874.

Wolfe, C.L., S. Hameed, and L. Chi. 2019. On the drivers of decadal variability of the Gulf Stream north wall. Journal of Climate 32(4):1,235-1,249, https://doi.org/10.1175/JCLI-D-18-0212.1.

\section{ACKNOWLEDGMENTS}

Support for this work was provided by grant 00032034 from the Lenfest Ocean Program of the Pew Charitable Trusts. The authors would like to thank Sandra Williams, Canadian Wildlife Federation, and Bruce Monger, Cornell University, for their assistance with illustrations, and Andrew Pershing, Gulf of Maine Research Institute, Lequan Chi, Skidaway Institute of Oceanography and Joseph Langan, University of Rhode Island, for their assistance with the updated analyses of the Continuous Plankton Recorder data, the GSI, and the RSWT, respectively. This work could not be done without the tireless efforts of the North Atlantic Right Whale Consortium and their partners. The Whiteley Center at the University of Washington's Friday Harbor Laboratories provided an intellectually vibrant setting for conducting several workshops associated with this study.

\section{AUTHORS}

Erin L. Meyer-Gutbrod (emgutbrod@seoe.sc.edu) is Assistant Professor, School of Earth, Ocean and Environment, University of South Carolina, Columbia, SC, USA. Charles H. Greene (chg2@cornell.edu) is Professor Emeritus, Ocean Resources and Ecosystems Program, Cornell University, Ithaca, NY, USA. Kimberley T.A. Davies is Assistant Professor, Department of Biological Sciences, University of New Brunswick, Saint John, New Brunswick, Canada. David G. Johns is Head, Continuous Plankton Recorder Survey, Marine Biological Association of the United Kingdom, Citadel Hill, The Hoe, Plymouth, UK.

\section{AUTHOR CONTRIBUTIONS AND POTENTIAL CONFLICTS OF INTEREST}

E.L.M.-G., C.H.G, and K.T.A.D. contributed to the data analyses, conceptual framing, and writing of this paper. E.L.M.-G. and C.H.G. contributed equally as lead authors in the writing of this paper. D.G.J. supervised the processing of Continuous Plankton Recorder survey samples and quality checking of the corresponding plankton abundance data. None of the authors have any financial interests that could be perceived as being a conflict of interest.

\section{ARTICLE CITATION}

Meyer-Gutbrod, E.L., C.H. Greene, K.T.A. Davies, and D.G. Johns. 2021. Ocean regime shift is driving collapse of the North Atlantic right whale population. Oceanography 34(3):22-31, https://doi.org/10.5670/ oceanog.2021.308.

\section{COPYRIGHT \& USACE}

This is an open access article made available under the terms of the Creative Commons Attribution 4.0 International License (https://creativecommons.org/ licenses/by/4.0/), which permits use, sharing, adaptation, distribution, and reproduction in any medium or format as long as users cite the materials appropriately, provide a link to the Creative Commons license, and indicate the changes that were made to the original content. 